\title{
Editorial
}

\section{A New Beginning for Cells Tissues Organs}

We are privileged to receive the warm welcome expressed by Thomas Karger from the Karger publishing family and by Hans-Werner Denker and Art English, the former editors in chief of Cells Tissues Organs. Our reply accompanies the first issue for which the new editorial triumvirate is responsible, and we hope that the contents mirror the new focus of the Journal: multiscale development in vivo and in vitro with an emphasis on human relevance. At the same time, a certain déjà vu in that mirror image is our full commitment to continuing on the path of innovation and knowledge acquisition laid out by our predecessors from the start of the Journal in 1945. What was then the establishment of the term functional anatomy in a field struggling with the correct representation of nature's wealth of forms is still with us today with the obligation to tackle the functional logic behind the attractive pictures we capture under our microscopes from these forms.

Scientific publishing in the 21st century may be changing drastically under the influence of electronic media. What has not changed, and will not change, is the need for rigour (next to reason) as being the most important factor in knowledge acquisition and dissemination since Homo sapiens amalgamated astronomy, mechanical physics, and metaphysics in building the Stonehenge monument without written language or instant access to big data. Aristotle (382-322 B.C.) postulated that "credit should be given to observation rather than to theory"1. For the future of Cells Tissues Organs, we would like to use the reference to this wisdom as reassurance and inspiration to follow new thoughts and methods in trying to understand human development and to improve the human condition.

The scientific portfolios of the three of us, which are reflected also by the choice of our associate editors and editorial board, cross all borders far and wide of our individual main interests as in tissue engineering (R.J.G.), stem cells (G.S.), and mammalian development (C.V.). They are - not least in com-

\footnotetext{
${ }^{1}$ Aristotle: On the Generation of Animals, book III p760b31-33.
} 
bination with our geographical positioning around the globe - intended to provide the broadest possible perspective and may be a model for international, interdisciplinary concerted action in carrying out life science research. Our "triad" constitution will encourage us to keep an open mind when making seemingly bipolar decisions on observation versus theory, correlation versus causality, (writing) creativity versus (reproducible) facts, speed versus quality, to name but a few current and everlasting problems. We will dedicate our full attention to a fair and efficient editorial processing of manuscripts entrusted to CTO and will always be supportive for our authors to make the best possible product from their research efforts.

Finally, we would like to express our deepest gratitude for having been given the chance to embark on this endeavor. We hope we can live up to the expectations in looking after Thomas Karger's precious gem.

Ryan J. Gilbert, Troy, NY

Guojun Sheng, Kumamoto City Christoph Viebahn, Göttingen 